\title{
Compositional situation: analysis of the location of two sculptures in Mexico City
}

\author{
Leszek Maluga \\ leszek.maluga@pwr.edu.pl \\ Department of Drawing, Painting and Sculpture, Faculty of Architecture, \\ Wroctaw University of Science and Technology
}

\begin{abstract}
The study consists of two parts. In the first one, the author outlines a methodological concept of researching the quality of compositional and artistic spatial systems that are created, for example, in the urban environment with the participation of, inter alia, architectural objects and works of art. The subject of this type of research was called a 'compositional situation'. In the second part, the author uses the proposed research method to analyze specific cases. These are two situations existing in the public spaces of Mexico City, in which sculptures of famous Mexican sculptor Sebastian were located.
\end{abstract}

Keywords: methodology, spatial composition, public space, sculpture, Mexico City

\section{Introduction}

One of the basic goals of architectural creative activity is searching for and building order of space [Szmidt 1981]. Creating order of space should be a skill that a designer masters in the process of education and develops it in professional practice. Knowledge in this area is acquired through the analysis of formal systems in spatial reality or on the basis of theoretical models, projects and visions. For this purpose, various research methods are used ${ }^{1}$.

A component of order of space (or spatial order) is formal order which is expressed, for example, through a spatial composition as a conscious and intentional configuration of a set of elements co-creating a specific system $^{2}$. Formal order can be defined by means of a set of concepts describing or controlling relationships between elements which occur in a given spatial system. This system is understood as a fragment of space having a certain structure. The relationships occurring in such a structure can be studied, measured and described using a specific system of concepts, and thus features of the system such as dimensions, number of elements, appearance, etc. can be defined. At the level of description of the physical form, generally accepted sets of concepts and parameters, e.g. numerical values, geometrical shapes and material features are sufficient. At the level of description in terms of composition and art, it is necessary to use concepts and terminology that are relevant to a particular creative situation. A set of such terms was collected and discussed in a study that was made in the Department of Drawing, Painting and Sculpture at the Faculty of Architecture of Wroclaw University of Technology in 2015 [Maluga 2015]. It presented a wide range of terms related to compositional topics which were divided into terms describing composition components, compositional relationships between components, features of compositional systems as well as compositional and artistic means, tools and materials used in creative activity.

1 The methodological concept of the compositional situation refers to research practices described by E. D. Niezabitowska in her work Research methods and techniques in architecture; as a mixed method it includes, inter alia, elements of methods of analysis as well as logical and interpretative structure and case studies [Niezabitowska 2014].

2 A number of different definitions of the concept of 'spatial composition' and other related terms can be found in the following study: L. Maluga with his team, Composition - selected problems in artistic, architectural and didactic artistic creative activity [Maluga 2014]. 


\section{Methodological concept of the 'compositional situation's}

A spatial composition - architectural, urban or landscape - is described in three main categories: form, structure and matter [Maluga 2016]. The next stage of the description and analysis can be the aesthetic interpretation of the work: presentation, significance, symbolism ${ }^{4}$. However, not every spatial arrangement, even representing a certain spatial (geometric) order is a composition. Therefore, for the purposes of description and analysis of a wider spectrum of spatial situations, the concept of compositional situation was proposed in these considerations. Consequently, this term is described as a methodological procedure consisting in defining, for research purposes, the space around a given artifact as its surroundings in relation to which there are compositional relationships. The artifact in this case (which constitutes the compositional situation) is sometimes an architectural object or ensemble, a composition of greenery, a sculpture, or another artistic work bringing specific compositional properties. Hence, the compositional situation is a broader concept than the term of composition (a single object or a complex), as it presupposes the examination of the relationship between a particular element and its spatial context. As a research concept of spatial structure, it also assumes the possibility of using it to analyze various spatial situations from architectural interiors to landscape interiors.

The idea of a spatial unit as a certain structure for research and design has appeared in the works of theoreticians of spatial composition, e.g. an architectural and landscape unit (landscape interior) in works of J. Bogdanowski [Bogdanowski 1976] or the concept of urban interior in works of K. Wejchert [Wejchert 1984]. Oskar Hansen, on the other hand, uses in his reflections on visual structures the term "situation consciously highlighted" as a tool of artistic interaction in the spatial environment. It is a situation of controlled use of form relations as opposed to any form relation in space [Hansen 2005, pp. 18-19]. In this approach, Hansen's term can be referred to the concept of a compositional system in which all elements are related by compositional relations. However, in a spatial reality there are many systems built of elements (being compositions in themselves) without consciously assumed mutual compositional relations, characterized by random, distorted spatial relations as a result of changes or incorrect design decisions.

Space has its own history. Sometimes construction projects arise in a pristine terrain without any cultural context. More often, especially in cities, new facilities are created in existing spatial arrangements and in the vicinity of already completed facilities. Therefore, they enter into spatial relations with previously created elements of the structure (with a context), adding or expressing the compositional and artistic values of the urban space. Each interference - a new implementation or change of the existing system - creates a new spatial and compositional situation.

An example of such a process is the reconstruction of Nowy Targ Square in Wrocław. The new functional and spatial structure of the square replaced the old one ${ }^{5}$. Thus, the existing frontages of the urban interior constitute the context for the new spatial arrangement. As a result of the implementation of the reconstruction project, a new compositional situation arose, which can be analyzed in terms of size and scale, structure, art etc. If there comes to any implementation decision, another compositional situation will be created in relation to the new square and surrounding buildings.

Spatial systems in which a new compositional form appears can be included in one of three following cases:

the area creates a coherent whole in terms of composition and art; it is a case of a complex work, e.g. hierarchical composition;

- the object creates a specific, more or less conscious compositional game with the context; compositional relationships arise that can be analyzed as part of the resulting compositional situation;

- the object is accidentally inserted into the context, which does not change the fact that spatial relationships arise in this situation, which can be described using compositional terminology; it is a spatial arrangement that can be called an apparent composition situation.

3 The term "compositional situation" was to some extent inspired by the term "aesthetic situation" by M. Gołaszewska.

4 A certain analogy may be the method of researching works of art developed by E. Ponfsky: pre-iconographic description, iconographic analysis and iconological analysis [Sławińska 1979].

5 The reconstruction of the Nowy Targ Square in Wrocław was carried out as a result of an architectural competition organized by the Municipal Office in Wrocław in 2010. The authors of the winning project that was to be implemented are Roman Rutkowski and Piotr Guliński; Nowy Targ Square in Wrocław, architektura.muratorplus.pl/zycie-w-architekturze/2015/plac-nowy-targ-we-wroclawiu/1353/ (access: 2016.09.23). 
What seems to be the key in the above distinction are the two following concepts - compositional awareness (designer's competences) and the intentionality of a creative act, which condition the possibility of qualifying specific features of an object or system as composition-artistic quality.

As part of the methodological concept of the situation, there are concepts that organize descriptions and analyzes, such as the boundaries of a compositional situation, a hierarchy of elements, compositional relations, individual artistic features of compositional elements. A compositional situation is also characterized by specific parameters regarding distance, size and number of elements.

In the research process of a compositional situation, its main components can be distinguished, which form the methodological sequence:

- description of the spatial layout,

description of individual elements of the situation,

quality analysis of plastic elements,

- analysis of compositional relations between elements,

artistic interpretation of the relationship (artistic expression, style, etc.),

aesthetic interpretation of the relationship (symbolism, object-place relationships, etc.).

The effect of the description and compositional analysis should be conclusions that, on the one hand, state certain creative attitudes in solving compositional situations, while on the other, they can indicate good practices in designing especially public spaces. In turn, the sum of analyzes of various compositional situations can be used to create typologies of compositional situations, theoretical models and to expand knowledge of the necessary spatial composition in teaching and creativity.

\section{Two sculptures by Sebastian in the public space of Mexico City}

The practical application of the research method described above is an analysis of two compositional situations in Mexico City, the capital of Mexico. The city has public spaces that are very diverse formally and culturally. In many places, architectural, urban and landscape structures are supplemented by artistic objects, mainly murals and sculptures. The introduction of intimate and monumental works of art enriches and modifies the compositional and artistic qualities of urban spaces. This is a characteristic feature of the cultural landscape of the Mexican capital. Two sculptures of the same author - famous Mexican sculptor Sebastian - set in two different places of the city created two different compositional situations. They will allow us to apply the proposed method of analysis.

Sebastián (real name Enrique Carbajal, born in 1947) creates monumental sculptures in Mexico and around the world. ${ }^{6}$ His style is referred to as "emotional geometry." Huge geometrized forms are characterized by dynamic shapes, soft curves, weaves and penetration of elements, perforations. These forms are mostly one-coloured in strong colours, usually in basic colours - yellow, red and blue.

\section{Sculpture El Caballito in Paseo de la Reforma (Fig. 1, 2, 3)}

On one of the most representative intersections of the capital, the sculpture of Sebastian El Caballito ("Small Horse") has been standing since 1992, named by the author "Head of a horse" Cabeza de caballo, 1991. It is made of steel and covered with a yellow acrylic coating. The name of the sculpture, and indirectly its form refer to the historical monument that stood at this intersection since the mid-nineteenth century.

The current compositional situation is marked by three important urban axes forming a vast intersection (which until 1979 took the form of a roundabout - Glorieta del Caballito), monumental buildings at the corners of the intersection and the sculpture itself. 

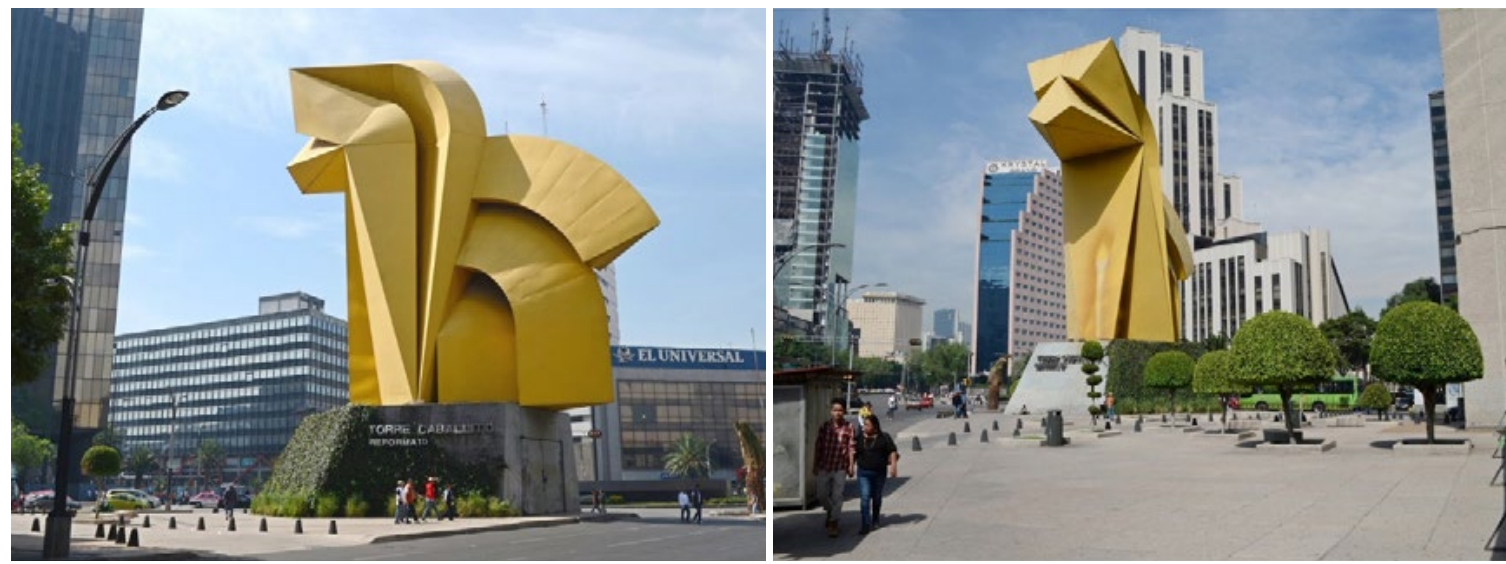

Fig. 1., 2. Various views of El Caballito sculpture Różne widoki rzeźby El Caballito

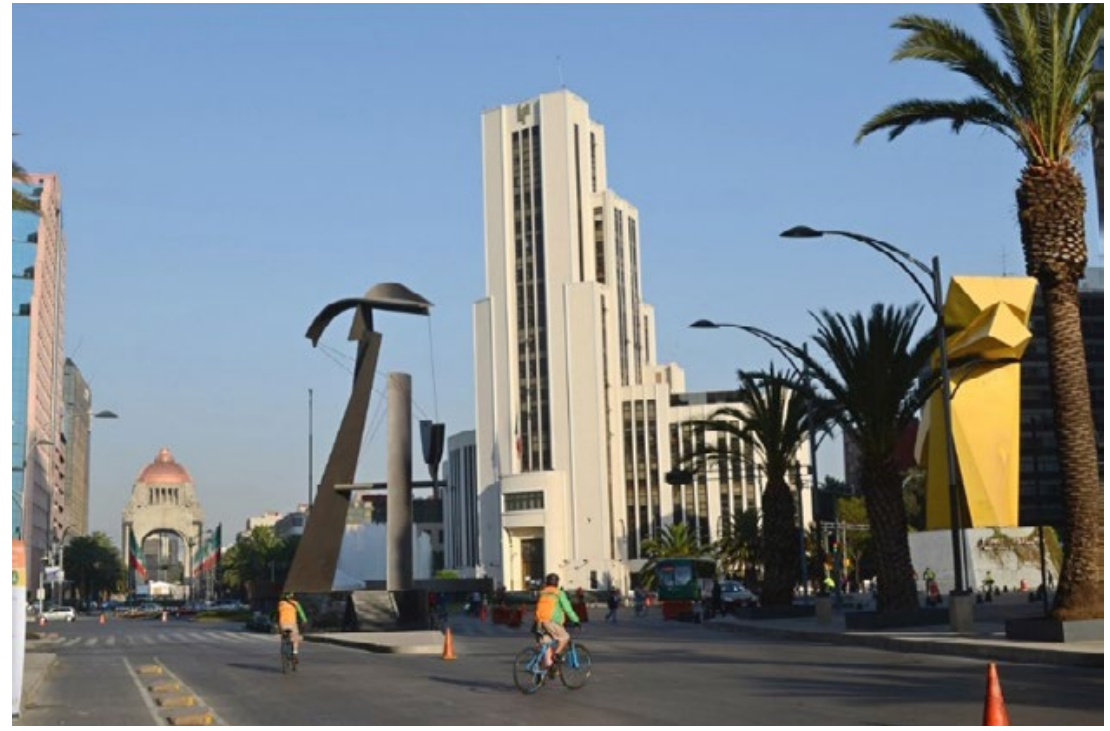

Fig. 3. Sculpture of M. Felguérez Puerta 1808 , in the background the Revolution Monument

Rzeźba M. Felguéreza Puerta 1808, w głębi Pomnik Rewolucji

The place has its history ${ }^{7}$. At the intersection of two streets going out from the city centre a circular square was created, on which in the early 1850s an equestrian statue of the Spanish King Charles IV was erected, later commonly called El Caballito ("Small Horse"). Shortly thereafter, an alley was marked out from this square leading west to Chapultepec Castle, then the seat of Emperor Maximilian I of Habsburg. This avenue, gradually expanded to the model of European metropolitan boulevards, in the following decades became the most representative artery of the City of Mexico.

The intersection in the form of a roundabout (Glorieta del Caballito) was maintained until 1979 and the equestrian statue of the king ( $E l$ Caballito) was moved to a new place in the Historical Centre after 127 years. The central place at the intersection was taken by a low round fountain. The new sculpture appeared only in 1992. However, it was set not in the middle of the intersection but on one of the northern corners in front of the newly erected tower called Torre del Caballito.

Within the intersection in the middle of the outlet of Juarez Street leading to the historic centre, another sculpture was placed under the name Puerta 1808 by Manuel Felguérez (2007), which was created to celebrate the $200^{\text {th }}$ anniversary of Mexico independence [Carvallo Robledo 2007, fig. 3]. It is lower, dark in colour and delicate in its openwork structure, so it does not compete with the sculpture of El Caballito. In contrast, the 
expressive form to some extent fits in with the abstract geometry imposed by Sebastian's work. It is prominent on the observation axis connecting the historical centre of the city with the monumental Revolution Monument on Republic Square located on the other side of the intersection at a distance of approx. $0.5 \mathrm{~km}$ (fig. 3).

El Caballito is visible from a greater distance only along the axis running north of Bucareli Street. From other directions it appears only at a closer distance. In these view openings, it clearly stands out with its vividness.

The cross point of these three communication axes creates a star-shaped intersection. A building with an individual form is situated at each of the six corners. The two tallest buildings, Torre del Caballito and Torre Prisma, are simple, slender blocks (cuboid and prism with a triangle base) with dark, glass facades. On the opposite side there is the post-modern Meliá building from the 1990s (now the Krystal Grand Reforma Uno hotel) with a step-shaped upper corner. The El Moro building (also called La Lotería as the business seat of Lotería Nacional) has the most extensive form, designed in the Art Deco style and completed in 1946. The symmetrical facade with strong vertical segments is emphasized by the slim central tower. The other two corners of the intersection are not distinguished by their form or size. Sebastian's sculpture must therefore compete with the formally diverse monumental architectural context.

The intersection is vast. The distances between opposite corners range from approx. 100 to $200 \mathrm{~m}$. The light of the streets converging at the intersection is a distance from approx. 40 to $60 \mathrm{~m}$. The highest building - Torre del Caballito is $135 \mathrm{~m}$ high. These figures show the spatial scale of the surroundings of the El Caballito sculpture. In such a spatial situation, the sculpture remains in compositional relations with the environment, which determine the compositional situation: relations of size, shape and matter.

First, the sculpture, which is $28 \mathrm{~m}$ high, is huge in relation to man, but small in relation to the nearby skyscrapers. However, it does not disappear visually because it is the only such clear element in the intersection space on an intermediate scale between the size of the buildings and the dimensions of greenery and urban infrastructure.

Secondly, the sculpture has an original shape. In spite of the competing buildings in the background, $E l$ Caballito stands out due to its high expression of form. Softly curved and overlapping angular segments of the composition create a sculptural form clearly distinguished from the relatively simple geometry of the environment. Soft lines in the surroundings appear only in the curvature of the facade of the El Moro building and in the building of one of the southern low corners. Stepped bevels are only found in the Kristal Grand Hotel building. Thus, the sculpture El Caballito as a compact weave of solids, walls and lines is significantly distinguished by the expression of shapes from the dominant orthogonal and diagonal order of the environment.

Thirdly, the sculptural matter also contrasts with the surroundings. In this case, Sebastian's work is made of steel sheet covered with an intense yellow acrylic coating. The pure colour of the sculpture makes it a very strong element of the spatial structure. It not only clearly cuts out from the background but also creates a strong colour contrast to other forms of the intersection (black skyscrapers, white El Moro building, pink façades of Kristal Grand hotels) and in relation to further gray urban landscape plans.

Sebastian's sculpture was made to order in a specific urban situation. Therefore, it should be assumed that all artistic decisions were made taking into account the existing conditions. Compositional relations are the artist's conscious spatial play in an urban environment. They constitute valuable experience in the field of integration of art with public space.

\section{Sculpture Colotl (1980) in Paseo de las Esculturas (CCU) (Fig. 4, 5, 6)}

The second compositional situation concerns a part of the area of the University Cultural Centre (CCU) in the south of the city, where the outdoor sculpture complex - Paseo de las Esculturas was placed. The exhibition between the monumental blocks of the centre buildings occupies a fragment of the area called Pedregal de San Ángel. It is part of a large lava field formed as a result of the eruption of the Xitle volcano in the $3^{\text {rd }}$ century $A D$ and covered with vegetation that has naturally developed on this soil. ${ }^{8}$ 

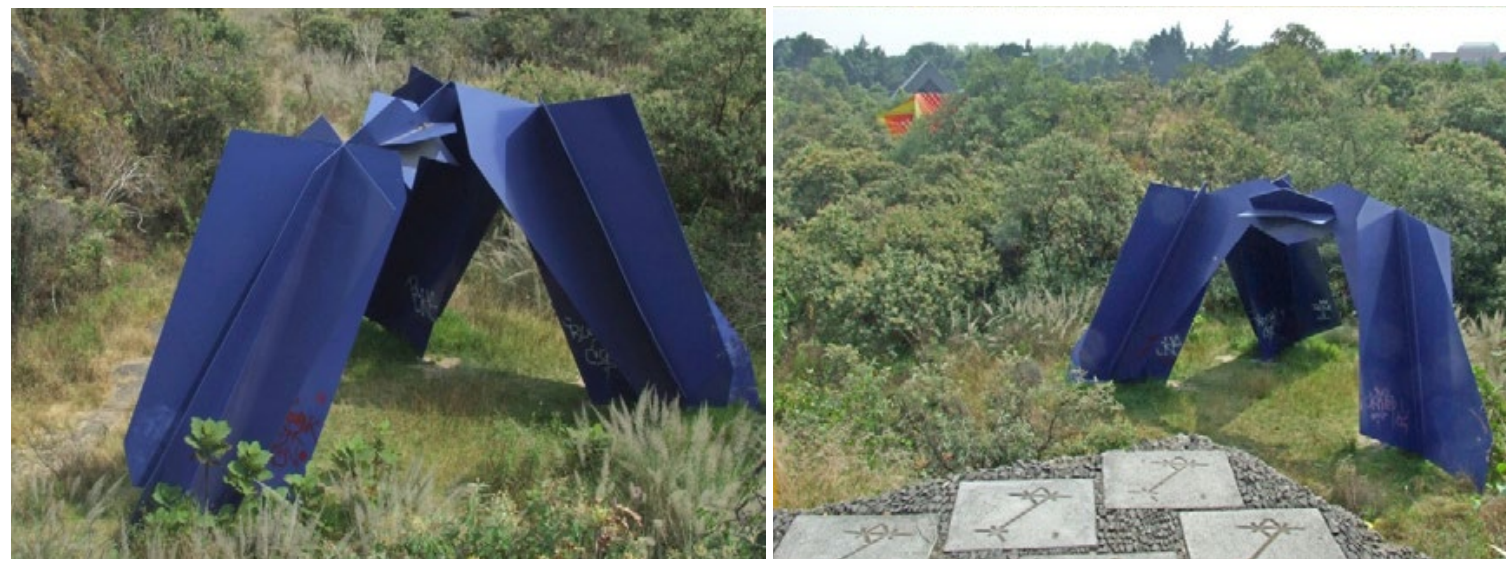

Fig. 4., 6. Sculpture of Sebastian Colotl

Rzeźba Sebastiana Colotl

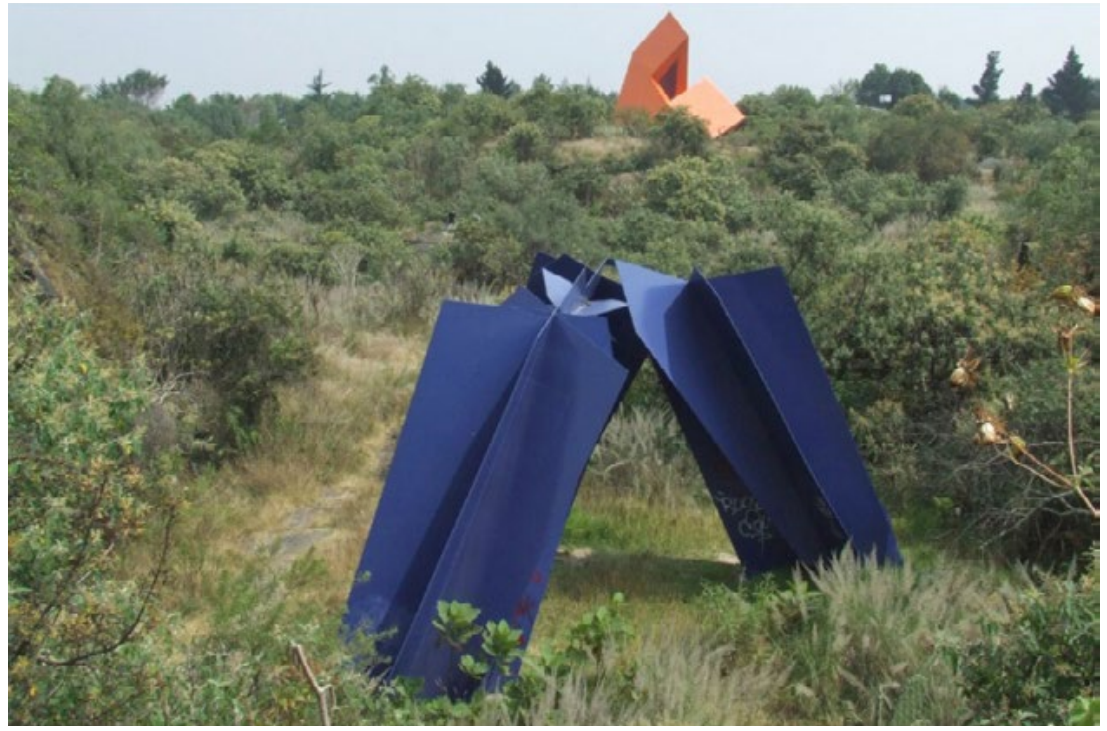

Fig. 5. Sculpture of Sebastian Colotl, in the background sculpture Ave dos (author: Hersúa)

Rzeźba Sebastiana Colotl, w głębi rzeźba Ave dos (autor: Hersúa)

The exhibition includes seven large sculptures authored by some famous Mexican artists ${ }^{9}$, co-authors of the nearby monumental sculptural and landscape composition - Espacio Escultorico (1979), forming a concrete circle around a field cleared of lava vegetation.

In the case of Paseo de las Esculturas, the sculptures are placed freely among the bushes at distances that prevent direct composition relations. Each form maintains autonomy in its immediate surroundings. It has a separate form, structure, colour and artistic convention referring in an original way to the language of geometry. The sculptures viewed from different places, however, are next to each other in the field of view - sometimes several at a time - co-creating a special cultural landscape. These views emphasize the effect of the ensemble, which "Sculpture Path" is by definition.

In the case of such an exhibition, a compositional situation can be considered on two scales. On a larger scale, the compositional situation is defined by monumental architectural blocks, an area of natural terrain and a complex of 7 sculptures. On a smaller scale, each of the sculptures constitutes its own compositional situation as a separate creation. 
Sebastian's sculpture is called Colotl, which means "Scorpio" in Nahuatl. Like the other sculptures - "Snake", "Rabbit" or "Bird" - it refers by the nameand to some extent its shape to animals that can inhabit Pedregal. In this way, geometrized abstract forms acquire meaning as a symbolic representation of the local fauna.

The sculpture has a dynamic form consisting of three obliquely connected legs strongly supporting each other on the ground. The angular tin elements in blue stand out strongly from the floral background.

In this case, Sebastian's sculpture remains in compositional relations with the natural surroundings, with other sculptural forms (fig. 6), and with the nearby buildings. In each of these combinations, the dominant compositional feature is formal and colourful contrast. The sculpture stands out from the surroundings with its pure colour but it competes with other colourful forms. The geometrized dynamic form contrasts with the softness of natural matter as well as the massive geometry of the building and the different forms of the other sculptures.

All the above mentioned compositional relations adopted in the artist's assumption have an impact on the creative effect, which is the clear expression of the form. The compositional formula is the opposite of the idea of soft adaptation to the landscape context. The sculptural form is therefore intended to cause compositional and artistic tensions in an environment dominated in spatial and visual categories by the contrast between concrete architectural blocks and the vast, flat and monotonous landscape of Pedregal.

\section{Conclusions}

Two examples of analysis of compositional situations from Mexico illustrate how to study specific spatial systems. The conclusions resulting from these analyzes enrich the knowledge that can be useful in solving design tasks in similar spatial situations.

Compositional relationships can be defined aposteriori as a result of analyzing particular cases (case studies) or can be adopted a priori as creative assumptions. The methodological concept of studying the compositional situation is a proposal for a method of building knowledge about spatial composition in various scales and environments. In practice, this knowledge should be used by designers to formulate and verify design assumptions.

Order of space is an expression of a broadly understood consensus between various approaches to the phenomenon of space and the related diverse needs for its use. While order in the sense of functional order can be verified by logical reasoning, order in the sense of spatial order is relatively easily understood in terms of basic geometric orders. On the other hand, compositional relations as an effect of a creative process do not have to be based on simple geometric relations. This is proved by contemporary works of art and architecture reaching out in search of new qualities of artistic borders of chaos.

That is why relatively few scientific studies raise the problems of composition and art as a research area. These issues are based on assessing the quality of solutions, and these are often subject to subjective ways of seeing and understanding works by those who describe them. It is, therefore, the domain of artistic criticism rather than objective scientific analysis.

This fact, however, does not undermine the need to search for methods of description and analysis which are free from emotions and subjective assessments. It is a way of developing knowledge on spatial composition as universal, not entangled with creative emotions, sphere of designers' competence and substantive support of decision-makers.

\section{Bibliography}

[1] Bogdanowski J. 1976: Composition and planning in landscape architecture (in Polish). ZN im. Ossolińskich, Kraków.

[2] Carvallo Robledo I., 2007, 1808 visto desde la Ciudad de México, www.nodulo.org/ec/2007/n068p04.htm (access: 2016.02.18).

[3] El Pedregal (Reserva Ecológica del Pedregal de San Ángel), www.repsa.unam.mx/index.php/pedregal-de-san-angel (access: 2016.02.17)

[4] Glorieta del Caballito, www.mexicomaxico.org/Reforma/reformaGlor.htm (access: 2013.08.23).

[5] Hansen O., 2005: To see the world (in Polish). Zachęta Narodowa Galeria Sztuki, Warszawa. 
[6] Maluga L. z zespołem, 2014: Composition - selected problemsof art, architecture and teaching (in Polish). Raport serii Sprawozdania nr S-05/14, Zakład Rysunku, Malarstwa i Rzeźby, Wydział Architektury Politechniki Wrocławskiej, Wrocław.

[7] Maluga L., A. Boyko, 2015: Fixed and variable orders in the light of new trends of architecture and town planning (in Polish). Raport serii SPR nr W1H / S-036/15, Zakład Rysunku, Malarstwa i Rzeźby, Wydział Architektury Politechniki Wrocławskiej, Wrocław.

[8] Niezabitowska D. E., 2014: Research methods and tecniques in architecture (in Polish). Wydawnictwo Politechniki Śląskiej, Gliwice.

[9] Paseo de las Esculturas o Sendero Escultórico de la UNAM, www.vivaelsur.mx/2012/02/paseo-de-las-esculturas-o-sendero-escultorico-de-la-unam (access: 2013.08.26)

[10] Nowy Targ Square in Wrocław (in Polish), architektura.muratorplus.pl/zycie-w-architekturze/2015/plac-nowy-targ-we-wroclawiu/1353/ (access: 2016.09.23).

[11] Sławińska J., 1979: Aesthetics for designers (in Polish). Wyd. Politechniki Wrocławskiej, Wrocław.

[12] Szmidt B., 1981: Order of space (in Polish). PIW, Warszawa.

[13] Wejchert K., 1984: Elements of urban composition (in Polish). Arkady, Warszawa.

[14] www.sebastianmexico.com/index.html (access: 2016.02.170.

\section{Sytuacja kompozycyjna: analiza usytuowania dwóch rzeźb w mieście Meksyk}

Streszczenie: Opracowanie składa się z dwóch części. W pierwszej autor zarysowuje koncepcję metodologiczną badania jakości kompozycyjno-plastycznych układów przestrzennych, jakie powstają np. w środowisku miejskim, z udziałem m.in. obiektów architektonicznych i dzieł sztuki. Przedmiot tego typu badań został nazwany "sytuacją kompozycyjną". W drugiej części wykorzystuje zaproponowaną metodę badań do przeprowadzenia analizy konkretnych przypadków. Są to dwie sytuacje przestrzeni publicznych miasta Meksyk, w których zostały zlokalizowane rzeźby znanego meksykańskiego rzeźbiarza Sebastiana.

Słowa kluczowe: metodologia, kompozycja przestrzenna, przestrzeń publiczna, rzeźba, Meksyk 